\title{
ВИЗНАЧЕННЯ ОПТИМАЛЬНИХ РЕЖИМІВ РУХУ МАНІПУЛЯТОРА ЗА ПРОЦЕС ПУСКУ (ГАЛЬМУВАННЯ) ПІД ЧАС РОБОТИ ЗА ОДНЄЮ 3 УЗАГАЛЬНЕНИХ КООРДИНАТ
}

АНОТАЦІЯ. Розглянуто метод розрахунку оптимальних режимів руху стріли маніпулятора разом з вантажем під час роботи за однією з узагальнених координат

Ключьові слова: маніпулятор, оптимізація, режими руху

АННОТАЦИЯ. Рассмотрен метод расчета оптимальных режимов движения стрелы манипулятора с грузом во время работы по одной из обобщенных координат

Ключевые слова: манипулятор, оптимизация, режимы движения

SUMMARY. The method of computation of the optimum modes of motion of boom manipulator is considered together with a load at motion on one of the generalized coordinates

Key words: manipulator, optimization, modes of movement

\section{Актуальність проблеми}

Маніпулятор - керуємий пристрій або машина для виконання рушійних функцій, аналогічним функціям руки людини при перенесенні об'єктів в просторі, оснащений робочим органом.

В сучасних умовах виробництва маніпулятори, в складі роботизованих технологічних комплексів або як окремі одиниці техніки, знаходять широке застосування. За їх допомогою освоюються нові технологічні процеси, які звільняють людину від багатьох видів стомлюючої, одноманітної, інколи небезпечної та складної роботи. Сучасні маніпулятори це - складні високотехнічні машини зі складними електронними системами керування.

Завдяки своєї універсальності маніпулятори широко застосовують на транспортних засобах в якості завантажувально розвантажувальних пристроїв, одноківшевих екскаваторів, а також підйомників. Найбільш розповсюджені на транспортних засобах $\epsilon$ крани - маніпулятори 3 гідроприводом.

При зміні вильоту стріли маніпулятора, в процесі пуску і гальмування, виникають складні коливальні процеси, які є наслідком зміни навантажень, перерозподілу енергії під час зміни напрямку руху, а також різкого гальмування стріли під дією іiі власної ваги [1]. Виникаючі коливання призводять до зменшення надійності та міжремонтного циклу машини, збільшують енергоємність процесу і час виконання необхідних операцій.

Все зазначене вище свідчить про необхідність розробки регульованих систем керування маніпулятора, які б за різних умов руху створювали плавність роботи, мінімізували тривалість виконання операцій та зменшили витрати енергії.

Мета статті - на прикладі руху стріли маніпулятора за однією 3 узагальнених координат дослідити характер зміни швидкості й прискорення привідних ланок маніпулятора та визначити оптимальні режими руху механічної складової його стріли.

\section{Викладення основного матеріалу}

Розглянемо динамічну модель стріли крана - маніпулятора 3 гідроприводом (рис.1), що складається зі стояка 1, підйомної стріли 2, поворотної рукояті 3 , висувної балки 4, вантажу 5 і привідних гідроциліндрів: підйомного 6, складання стріли 7 та висувної балки 8. Живлення робочою рідиною привідних гідроциліндрів забезпечують два гідронасоса НШ-32, що входять в гідросхему крана.

Дана модель має три ступені вільності на площині, які визначаються положенням поршнів привідних гідроциліндрів. Розглянемо випадок, коли рух стріли відбувається лише за однією з узагальнених координат, 
наприклад під час роботи підйомного гідроциліндра. Позначимо незалежну узагальнену координату як $q_{1}$ - положення поршня висувного гідроциліндра.

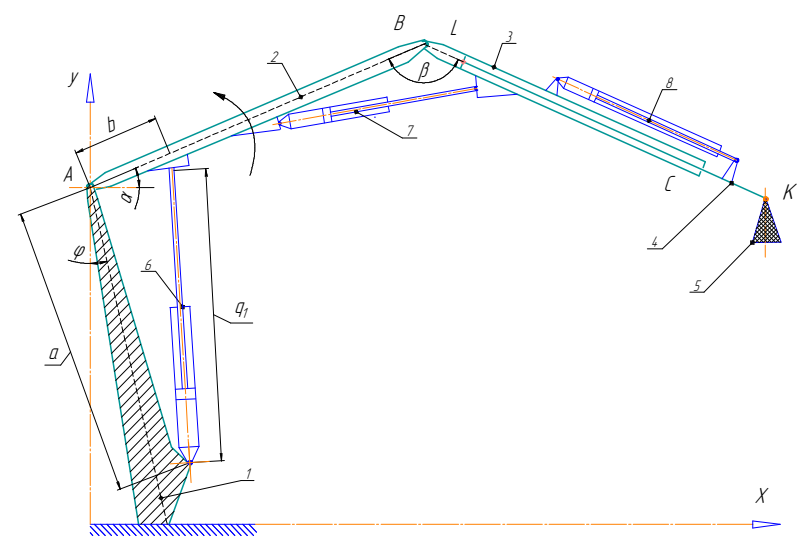

Рис. 1. Динамічна модель крана - маніпулятора

Для динамічної моделі стріли, що дається, визначимо оптимальний режим руху за процес вильоту вантажу.

Оптимальний енергетичний режим руху визначається мінімізацією критеріальної дії за Лагранжем, що представлена функціоналом 3 підінтегральною функцією у вигляді кінетичної енергії стрілової системи за крайових умов: початковими $t=t_{n}=0, q_{1}=q_{1 n}$ і кінцевими $t=t_{k}=t_{1}, q_{1}=q_{1 k}[1]$;

$$
I=\int_{t_{n}}^{t_{k}} E_{\kappa}\left(t, q_{1}, \dot{q}_{1}\right) d t
$$

Кінетична енергія стрілової системи, що зображена на рис.1,

$$
E_{k}=\frac{1}{2} J_{\Sigma \alpha} \dot{\alpha}^{2}
$$

де $J_{\Sigma \alpha}-$ зведений до осі обертання стріли момент інерції стрілової системи маніпулятора з вантажем; $\dot{\alpha}$ - кутова швидкість руху стрілової системи; $t_{n}, t_{k}$ - початковий і кінцевий моменти часу закінченого циклу руxy.

Розглядається рух лише підйомного гідроциліндра 6 (рис.1), оскільки гідроциліндри 7 та 8 нерухомі та разом 3 підйомною стрілою 2, рукояттю 3 та висувною балкою 4 створюють жорстку схему стріли.

Приведений момент інерції стріли маніпулятора в загальному випадку буде
$J_{\Sigma \alpha}=B C^{2}\left(\frac{m_{3}}{3}+m_{5}\right)+A B^{2}\left(\frac{m_{2}}{3}+m_{3}+m_{4}+m_{5}\right)+$

$+2 B C \cdot m_{5} \cdot q_{3}+\left(m_{4}+m_{5}\right) \cdot q_{3}^{2}+\frac{1}{3} L K \cdot m_{4}\left(L K+q_{3}\right)-$

$-\left(A B \cdot B C \cdot m_{3}+L K \cdot m_{4}+2 A B \cdot B C \cdot m_{3}+2 \cdot\left(m_{4}+\right.\right.$

$\left.\left.+A B \cdot m_{5}\right) \cdot q_{3}\right) \cdot \operatorname{Cos}(\beta)$,

де $m_{2}, m_{3}, m_{4}, m_{5}$ - відповідно маси підйомної і складаної стріли, висувної балки та вантажу.

Кутова швидкість стріли маніпулятора пов'язана 3 узагальненою координатою залежністю

$$
\dot{\alpha}=\dot{q}_{1} \frac{\partial \alpha}{\partial q_{1}}
$$

де $\frac{\partial \alpha}{\partial q_{1}}$ - оператор передачі руху першого порядку, який пов'язує координати стріли 3 координатою підйомного гідроциліндра.

Кут повороту стріли $\alpha$ визначається положенням узагальнюючої координати $q_{1}$ залежністю

$$
\alpha=\arccos \left(\frac{a^{2}+b^{2}-q_{1}^{2}}{2 a b}\right)-\varphi,
$$

де $a=1,4 \mathrm{M} ; b=0,29 \mathrm{M}-$ установчі розміри підйомного гідроциліндра (рис. 1 ); $\varphi=70^{\circ}-$ кут відхилення стояка стріли від вертикалі.

Оптимальний енергетичний режим руху стрілової системи визначається рівнянням Ейлера - Пуассона [2]

$$
\frac{\partial E_{k}}{\partial q_{1}}-\frac{d}{d t} \frac{\partial E_{k}}{\partial \dot{q}_{1}}=0
$$

Після виконаних замін та перетворень отримаємо крайову задачу

$$
J_{\Sigma \alpha}\left(\ddot{q}_{1}\left(\frac{\partial \alpha}{\partial q_{1}}\right)^{2}+\dot{q}_{1}^{2} \frac{\partial^{2} \alpha}{\partial q_{1}^{2}} \frac{\partial \alpha}{\partial q_{1}}\right)=0 .
$$

Рівняння (7) $є$ нелінійним диференційним рівнянням зі змінними коефіцієнтами. Для його розв' язку використаємо наближений числовий метод колокацій.

При використанні методу колокацій [3] розв'язок крайової задачі (7) визначаємо

$$
q_{1}=q_{1 n}+\left(\Delta q_{1}+\left(1-\frac{t}{t_{1}}\right)\left(a_{1}+a_{2} \frac{t}{t_{1}}\right)\right) \cdot\left(\frac{t}{t_{1}}\right)
$$


$\dot{q}_{1}=\left(\begin{array}{l}\Delta q_{1}+a_{1}\left(1-2 \frac{t}{t_{1}}\right)+a_{2} \frac{t}{t_{1}} \times \\ \times\left(2-3 \frac{t}{t_{1}}\right)\end{array}\right) \cdot \frac{1}{t_{1}} ;$

$\ddot{q}_{1}=2\left(a_{2}\left(1-3 \frac{t}{t_{1}}\right)-a_{1}\right) \cdot \frac{1}{t_{1}^{2}}$,

де $\Delta q_{1}=q_{1 k}-q_{1 n} ; \frac{t}{t_{1}}$ - відносна координата часу; $t_{1}$ - тривалість ділянки руху стріли маніпулятора; $a_{1}, a_{2}$ - сталі коефіцієнти рівнянь неув'язок в точках колокації. Точками колокацій вибрано точки: $\frac{t}{t_{1}}=\frac{1}{3} ; \frac{t}{t_{1}}=\frac{2}{3}$.

Після підстановки цих значень в залежності (8) отримаємо:

для $\frac{t}{t_{1}}=\frac{1}{3}$;

$q_{1}=q_{1 n}+\left(\Delta q_{1}+\frac{2}{3}\left(a_{1}+a_{2} \frac{1}{3}\right)\right) \cdot \frac{1}{3} ;$

$\dot{q}_{1}=\left(\Delta q_{1}+\left(a_{1}+a_{2}\right) \frac{1}{3}\right) \cdot \frac{1}{t_{1}} ;$

$\ddot{q}_{1}=\frac{-2 a_{1}}{t_{1}^{2}} ;$

для $\frac{t}{t_{1}}=\frac{2}{3}$;

$q_{1}=q_{n}+\left(\Delta q_{1}+\frac{1}{3}\left(a_{1}+a_{2} \frac{2}{3}\right)\right) \cdot \frac{2}{3} ;$

$\dot{q}_{1}=\left(\Delta q_{1}-a_{1} \frac{1}{3}\right) \cdot \frac{1}{t_{1}} ;$

$\ddot{q}_{1}=\frac{-2\left(a_{1}+a_{2}\right)}{t_{1}^{2}}$.

Визначивши в точках колокацій неув'язку рівнянь (7), отримаємо систему трансцендентних рівнянь 3 невідомими коефіцієнтами $a_{1}$ i $a_{2}$

$$
a_{1\left(\frac{1}{3}\right)}=\frac{\left(\Delta q_{1}+\frac{a_{1}+a_{2}}{3}\right)^{2} \cdot A_{1}}{2} ;
$$

$$
\begin{gathered}
a_{2\left(\frac{2}{3}\right)}=\frac{\left(\Delta q_{1}-\frac{a_{1}}{3}\right)^{2} \cdot A_{2}}{2}-a_{1}, \\
\text { де } A_{i}=\frac{\left(\frac{\partial \alpha}{\partial q_{1, i}} \frac{\partial^{2} \alpha}{\partial q_{1, i}{ }^{2}}\right)}{\left(\frac{\partial \alpha}{\partial q_{1, i}}\right)^{2}}, i=1 ; 2-\text { вирази, що }
\end{gathered}
$$
відповідають кутовим координатам стріли в точках колокацій.

Розглянемо ділянку руху з наступними значеннями: $q_{1 n}=1,49 \mathrm{M} ; q_{1 k}=1,66 \mathrm{~m} ; t_{k}=6 \mathrm{c}$.

Для заданих параметрів руху після багаторазової ітерації із рівняння (11) знаходимо невідомі коефіцієнти $a_{1}=0,057 \quad \mathrm{i}$ $a_{2}=0,017$. Графіки зміни швидкості та прискорення узагальнюючої координати зображені на рис. 2.
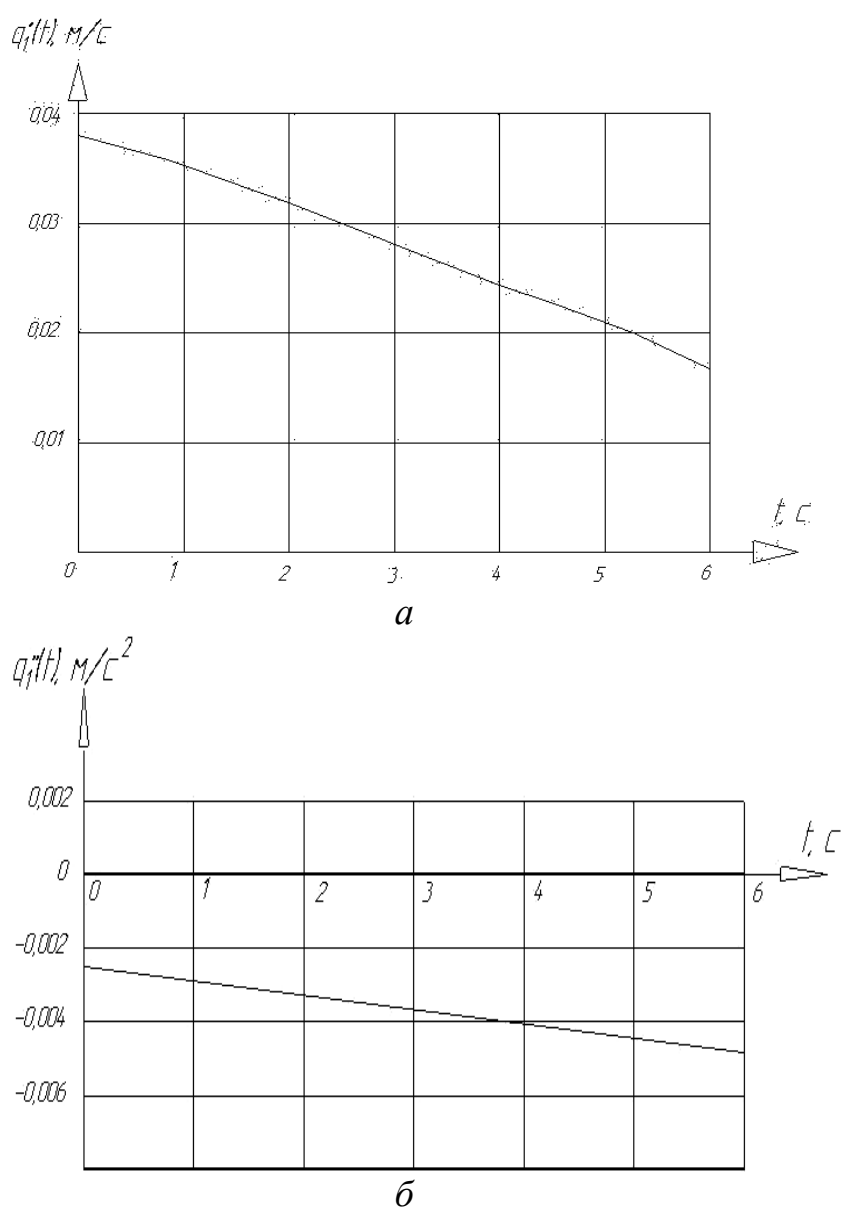

Рис.2. Характер зміни швидкості (a) та прискорення (б) узагальненої координати при енергетичному режимі руху 
Характеристики зображені на рис.2 дають можливість зробити висновок, що такий режим руху можна отримати лише на ділянці усталеного руху.

Оптимальний динамічний режим руху механічної складової частини стрілової системи маніпулятора визначається шляхом мінімізації інтегрального функціоналу з підінтегральною функцією у вигляді енергії прискорень

$$
I=\int_{t_{0}}^{t_{1}} E_{n}\left(t, q_{1}, \dot{q}_{1}, \ddot{q}_{1}\right) d t .
$$

В такому разі енергія прискорень стрілової системи, зображеної на рис.1, матиме вигляд

$$
E_{n}=\frac{1}{2} J_{\Sigma \alpha} \ddot{\alpha}^{2} .
$$

Координати прискорення стріли маніпулятора пов'язані з узагальнюючою координатою підйомного гідроциліндра наступною залежністю:

$$
\ddot{\alpha}=\ddot{q}_{1} \frac{\partial \alpha}{\partial q_{1}}+\dot{q}_{1} \frac{\partial^{2} \alpha}{\partial q_{1}^{2}} .
$$

Після підстановки виразу (14) у залежність (13) отримаємо енергію прискорень механічної складової стрілової системи за зміну вильоту вантажу, що виражається через узагальнюючу координату, її швидкість і прискорення

$$
E_{n}=\frac{1}{2} J_{\Sigma \alpha}\left(\ddot{q}_{1} \frac{\partial \alpha}{\partial q_{1}}+\dot{q}_{1} \frac{\partial^{2} \alpha}{\partial q_{1}^{2}}\right)^{2} .
$$

Оптимальний динамічний режим руху стрілової системи визначається рівнянням Ейлера - Пуассона

$$
\frac{\partial E_{n}}{\partial q_{1}}-\frac{d}{d t} \frac{\partial E_{n}}{\partial \dot{q}_{1}}+\frac{d^{2}}{d t^{2}} \frac{\partial E_{n}}{\partial \ddot{q}_{1}}=0 .
$$

У результаті отримуємо крайову задачу:

$$
\begin{aligned}
& J_{\Sigma \alpha}\left(q_{1}\left(\frac{\partial \alpha}{\partial q_{1}}\right)^{2}+\left(4 \dddot{q}_{1} \dot{q}_{1}+3 \ddot{q}_{1}^{2}\right) \frac{\partial^{2} \alpha}{\partial q_{1}{ }^{2}} \frac{\partial \alpha}{\partial q_{1}}+\right. \\
& \left.+\dot{q}_{1}^{2}\left(6 \ddot{q}_{1} \frac{\partial \alpha}{\partial q_{1}} \frac{\partial^{3} \alpha}{\partial q_{1}{ }^{3}}+\dot{q}_{1}^{2} \frac{\partial \alpha}{\partial q_{1}} \frac{\partial^{4} \alpha}{\partial q_{1}{ }^{4}}\right)\right)=0
\end{aligned}
$$

де крайові умови наступні: початкові $t=t_{n}=0, \quad q_{1}=q_{1 n}, \quad \dot{q}_{1}=\dot{q}_{1 n}=0 ;$ кінцеві $t=t_{k}=t_{1}, q_{1}=q_{1 k}, \dot{q}_{1}=\dot{q}_{1 k}=0$.
Крайову задачу (17) розв'язуємо методом колокацій. Розв'язок поставленої задачі визначаємо у наступному вигляді:

$$
\begin{aligned}
& q_{1}=q_{1 n}+\left(\frac{t}{t_{1}}\right)^{2}\left(\Delta q_{1}\left(3-2 \frac{t}{t_{1}}\right)+b\left(1-2 \frac{t}{t_{1}}+\left(\frac{t}{t_{1}}\right)^{2}\right)\right) ; \\
& \dot{q}_{1}=\left(3 \Delta q_{1}\left(1-\frac{t}{t_{1}}\right)+b\left(1-3 \frac{t}{t_{1}}+2\left(\frac{t}{t_{1}}\right)^{2}\right)\right) \cdot \frac{2 t}{t_{1}{ }^{2}} \\
& \ddot{q}_{1}=\left(3 \Delta q_{1}\left(1-2 \frac{t}{t_{1}}\right)+b\left(1-6 \frac{t}{t_{1}}+6\left(\frac{t}{t_{1}}\right)^{2}\right)\right) \cdot \frac{2}{t_{1}^{2}} ; \\
& \dddot{q}_{1}=-\left(\Delta q_{1}+b\left(1-2 \frac{t}{t_{1}}\right)\right) \cdot \frac{12}{t_{1}{ }^{3}} \\
& I_{V}=\frac{24 b}{q_{1}^{4}} .
\end{aligned}
$$

Точкою колокацій обрано точку $\frac{t}{t_{1}}=0,5$, після підстановки якої в залежність (18) отримаємо:

$$
\begin{aligned}
& q_{1}=q_{1 n}+0.25 \cdot\left(2 \cdot \Delta q_{1}+0.25 \cdot b\right) ; \\
& \dot{q}_{1}=\frac{1.5 \cdot \Delta q_{1}}{t_{1}} ; \ddot{q}_{1}=\frac{-b}{t_{1}{ }^{2}} ; \dddot{q}_{1}=\frac{-12 \Delta q_{1}}{t_{1}{ }^{2}} ; \\
& { }^{I V} q_{1}=\frac{24 b}{t_{1}{ }^{4}} .
\end{aligned}
$$

Розв'язавши в точках колокацій неув'язку рівнянь (17), отримаємо квадратне рівняння відносно невідомого параметра, який визначаємо наступним чином:

$$
\begin{gathered}
b=\left(3 \cdot \Delta q_{1}^{2}-0.125 \cdot b^{2}\right) \cdot B_{1}+0.0937 \times \\
\times \Delta q_{1}^{2}\left(6 \cdot b \cdot B_{2}-2.25 \cdot \Delta q_{1}^{2} \cdot B_{3}\right), \\
\text { де } B_{1}=\frac{\frac{\partial^{2} \alpha}{\partial q_{1}^{2}}}{\frac{\partial \alpha}{\partial q_{1}}} ; B_{2}=\frac{\frac{\partial^{3} \alpha}{\partial q_{1}^{3}}}{\frac{\partial \alpha}{\partial q_{1}}} ; B_{3}=\frac{\frac{\partial^{4} \alpha}{\partial q_{1}^{4}}}{\frac{\partial \alpha}{\partial q_{1}}} \text { - вира- }
\end{gathered}
$$

зи відношень передаточних функцій механізму стріли маніпулятора, які визначені в точці колокаій.

Для заданих параметрів стрілової системи маніпулятора розв' язано рівняння (20) і визначено невідомий коефіцієнт $b=0,403$.

Графіки зміни швидкості та прискорення узагальнюючої координати зображені на рис.3. 3 отриманих залежностей можна зробити висновок, що створити динамічний режим руху для даного крана - маніпуля- 
тора можливо за умов, що механізм приводу (в нашому випадку - підйомний гідроциліндр) забезпечить максимальну швидкість більш ніж 4,8cм/c за узагальненою координатою.
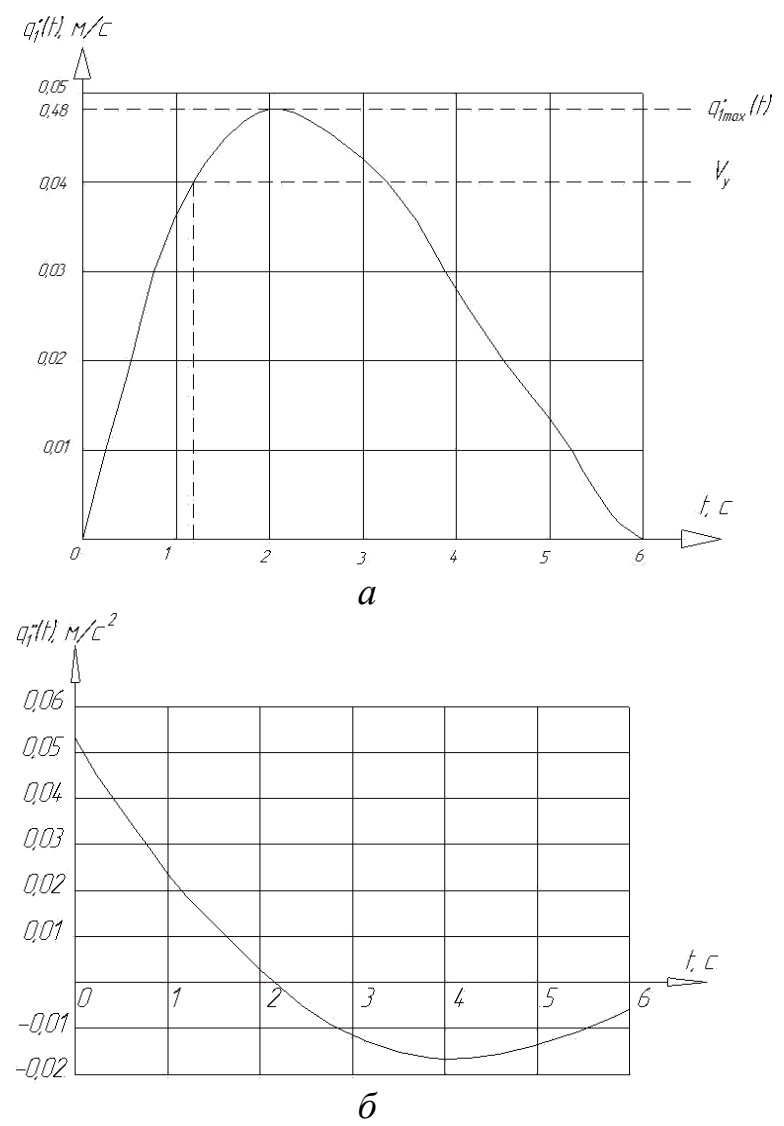

Рис.3. Характер зміни швидкості (a) та прискорення (б) узагальненої координати під час динамічного режиму руху

Максимальна швидкість висування штока гідроциліндра залежить від параметрів гідросистеми і в спрощеному випадку визначається 3 рівняння витрат робочої рідини за умов, що працює лише один підйомний циліндр [4], тобто

$$
V_{y}=\frac{2 \cdot Q}{S_{1}},[\mathrm{M} / \mathrm{c}],
$$

де $Q$ - робоча подача гідронасоса, $\mathrm{m}^{3} / \mathrm{c} ; S_{1}$ робоча площа поршня гідроциліндра, $\mathrm{m}^{2}$ :

$Q=\frac{q_{n} \cdot n}{60}=\frac{32 \cdot 1100}{60 \cdot 10^{6}}=0.000586\left[\mathrm{~m}^{3} / \mathrm{c}\right]$

$S_{1}=\frac{\pi D_{1}^{2}}{4}=\frac{3.14 \cdot 0.18^{2}}{4}=0.0025434\left[\mathrm{M}^{2}\right]$,

де $q_{n}$ - робоча подача гідронасоса, $\mathrm{cm}^{3} /$ об; $n$ - робоча частота насоса, об/хв; $D_{1}$ - діаметр поршня підйомного гідроциліндра (прийнято 180мм), м.

Після підстановок отриманих значень виразів (22) та (23) в залежність (21), отримаємо:

$$
V_{y}=\frac{2 \cdot 0.000586}{0.0025434}=0.046[\mathrm{~m} / \mathrm{c}] .
$$

Приймемо, що в процесі роботи маніпулятора, під час руху підйомної стріли, максимальна швидкість висування штока гідроциліндра становитиме $4 \mathrm{~cm} / \mathrm{c}$, віддаючи $15 \%$ від іï розрахункового значення на втрати в гідросистемі та похибку.

Із графіка (рис.3.а) видно, що прийняту швидкість поршень підйомного гідроциліндра (узагальнююча координата) набуває майже миттєво, протягом 1с, відразу після пуску системи. В реальних гідросистемах маніпуляторів час пуску гідроциліндра становить 2...3c, що зменшує динамічні навантаження, тому поки що, не вдаючись в детальний розрахунок гідросистеми приводу маніпулятора і визначення часу іiі запуску, приймемо час необхідний для пуску і гальмування - 3c та розглянемо оптимальний динамічний режим пуску і гальмування маніпулятора.

Оптимальний динамічний режим руху стрілової системи буде визначатися крайовою задачею (17), проте матиме інші граничні умови.

При пуску граничні умова наступні: початкові $-t=t_{0}=0, q=q_{n}, \dot{q}=0$; кінцеві $t=t_{1}=t_{n}, \dot{q}=V_{y}, \ddot{q}=0$. Розв'язок поставленої задачі також шукаємо методом колокацій, за яким він матиме наступний загальний вигляд:

$$
\begin{aligned}
q_{1} & =q_{1.0}+V_{y}\left(1-\frac{t}{3 \cdot t_{n}}\right) \frac{t^{2}}{t_{n}}+ \\
& +b\left(6 \frac{t^{2}}{t_{n}{ }^{2}}-15 \frac{t}{t_{n}}+10\right) \frac{t^{3}}{t_{n}{ }^{3}} \\
\dot{q}_{1} & =V_{y}\left(2-\frac{t}{t_{n}}\right) \frac{t}{t_{n}}+30 b\left(\frac{t^{2}}{t_{n}{ }^{2}}-2 \frac{t}{t_{n}}+1\right) \frac{t^{2}}{t_{n}{ }^{3}} ; \\
\ddot{q}_{1} & =V_{y}\left(1-\frac{t}{t_{n}}\right) \frac{1}{t_{n}}+60 b\left(2 \frac{t^{2}}{t_{n}{ }^{2}}-3 \frac{t}{t_{n}}+1\right) \frac{t}{t_{n}^{3}} ;
\end{aligned}
$$




$$
\begin{aligned}
& \dddot{q}_{1}=-V_{y} \frac{2}{t_{n}{ }^{2}}+60 b\left(6 \frac{t^{2}}{t_{n}{ }^{2}}-6 \frac{t}{t_{n}}+1\right) \frac{1}{t_{n}{ }^{3}} \\
& q_{1}=360 \cdot b\left(2 \frac{t}{t_{n}{ }^{2}}-\frac{1}{t_{n}}\right) \cdot \frac{1}{t_{n}{ }^{3}} .
\end{aligned}
$$

Точкою колокацій вибрано точку $\frac{t}{t_{n}}=0,5$ після підстановки якої в залежності (25) отримаємо

$$
\begin{aligned}
& q_{1}=q_{1.0}+V_{y} \cdot(0.415 \cdot t)+0.5 \cdot b ; \\
& \dot{q}_{1}=0.75 \cdot V_{y}+1.875 \cdot b \cdot \frac{1}{t_{n}} ; \ddot{q}_{1}=V_{y} \cdot \frac{1}{t_{n}} ; \\
& \dddot{q}_{1}=-V_{y} \cdot \frac{2}{t_{n}{ }^{2}}-30 \cdot b \cdot \frac{1}{t_{n}{ }^{3}} ; q_{1}=0 .
\end{aligned}
$$

Визначивши в точці колокацій неув' язку рівнянь, отримаємо параметричне рівняння при розв' язку якого вираховуємо невідомий коефіцієнт $b=0,00374$ при підстановці якого в залежності (25) отримуємо кінематичні характеристики стріли (рис.4), які відповідають оптимальному динамічному режиму пуску стрілової системи за процес зміни вильоту.
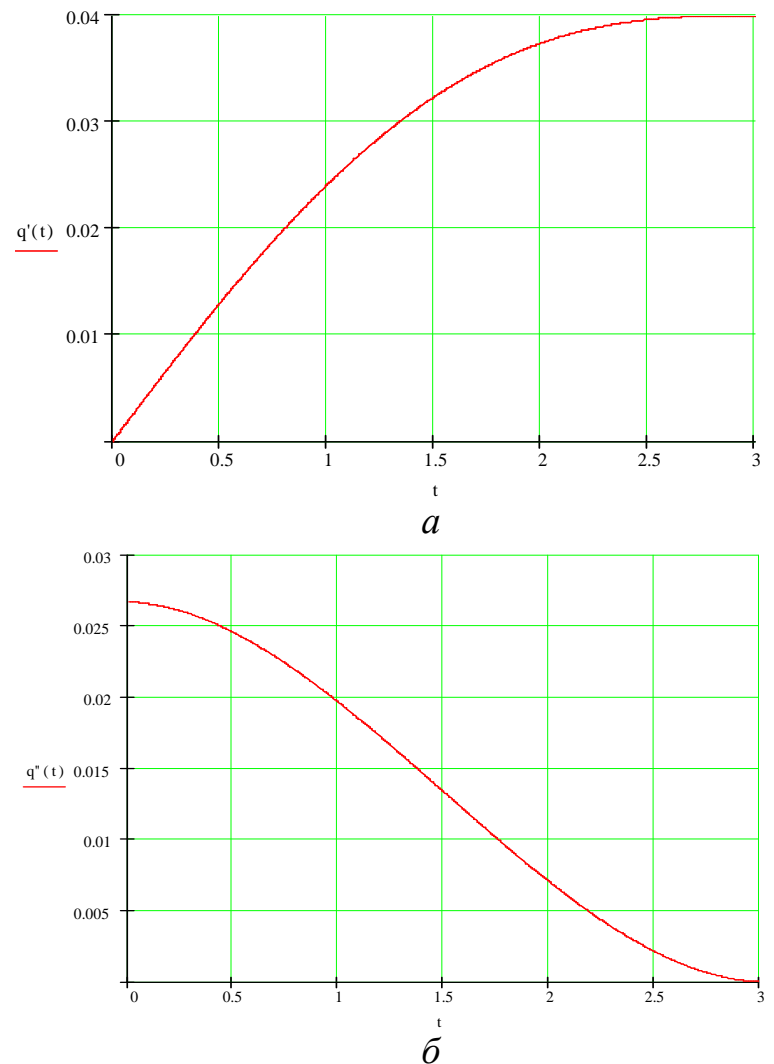

Рис.4. Характер зміни швидкості (a) та прискорення (б) узагальненої координати під час динамічного режиму пуску
При гальмуванні стрілової системи граничні умови наступні: початкові $t=t_{0}=0, \quad \dot{q}=V_{y}, \quad \ddot{q}=0 ; \quad$ кінцеві $t=t_{1}=t_{2}, q_{1}=q_{\kappa}, \dot{q}=0$. Розв' язок поставленої задачі буде

$$
\begin{aligned}
q_{1}= & q_{1 k}-V_{y}\left(\frac{2}{3} t_{k}-t+\frac{t^{3}}{3 \cdot t_{k}^{2}}\right)- \\
& -b\left(\frac{t^{5}}{t_{k}^{5}}-2 \frac{t^{4}}{t_{k}^{4}}+\frac{t^{3}}{t_{k}^{3}}\right) ; \\
\dot{q}_{1}= & V_{y}\left(1-\frac{t^{2}}{t_{k}^{2}}\right)-b\left(5 \frac{t^{4}}{t_{k}^{5}}-8 \frac{t^{3}}{t_{k}^{4}}+3 \frac{t^{2}}{t_{k}^{3}}\right) ; \\
\ddot{q}_{1}= & -2 V_{y} \frac{t}{t_{k}^{2}}-b\left(20 \frac{t^{3}}{t_{k}^{5}}-24 \frac{t^{2}}{t_{k}^{4}}+6 \frac{t}{t_{k}^{3}}\right) ; \\
\dddot{q}_{1}= & -V_{y} \frac{2}{t_{n}^{2}}-b\left(60 \frac{t^{2}}{t_{k}^{5}}-48 \frac{t}{t_{k}^{4}}+6 \frac{1}{t_{k}^{3}}\right) ; \\
I V & -b\left(120 \frac{t}{t_{k}^{5}}-48 \frac{1}{t_{k}^{4}}\right) \cdot
\end{aligned}
$$

Точкою колокацій вибрано $\frac{t}{t_{n}}=0,5$ після підстановки якої в залежності (27) отримаємо:

$$
\begin{aligned}
& q_{1}=q_{1 . k}-V_{y}\left(\frac{2}{3} t_{k}-0.916 t\right)-0.03135 b \\
& \dot{q}_{1}=0.75 V_{y}-0.0625 \cdot b \frac{1}{t_{k}} ; \ddot{q}_{1}=-V_{y} \frac{1}{t_{k}^{2}}+0.5 \frac{b}{t_{k}^{2}} ; \\
& \dddot{q}_{1}=-V_{y} \frac{2}{t_{k}^{2}}+3 \cdot b \frac{1}{t_{k}^{3}} ; q_{1}=-12 \frac{b}{t_{k}^{4}} .
\end{aligned}
$$

Визначивши в точці колокацій неув' язку рівнянь, отримаємо параметричне рівняння при розв' язку якого вираховуємо невідомий коефіцієнт $b=-0,004919$ після підстановки якого в залежності (27) отримуємо графіки кінематичних характеристик стріли (рис.5), які відповідають оптимальному динамічному режиму гальмування стрілової системи в процесі зміни вильоту. 


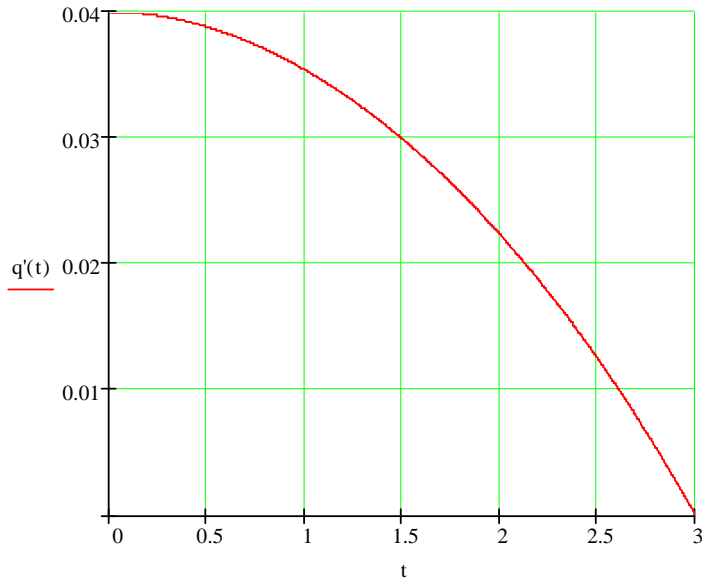

$a$

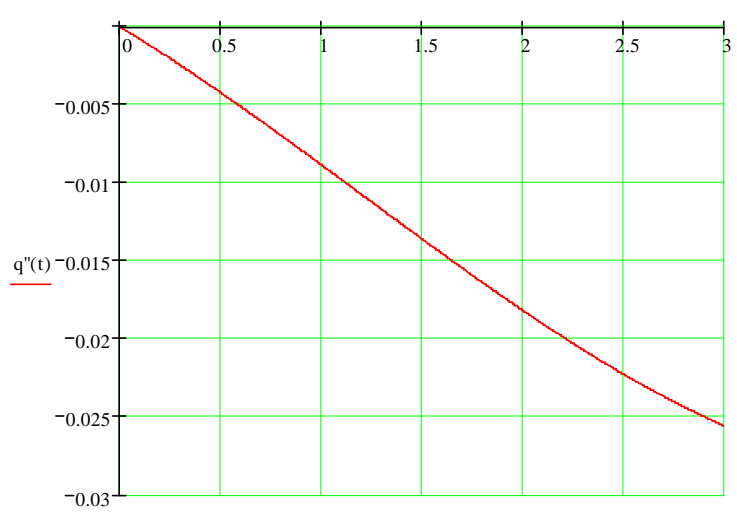

6

Рис.5. Характер зміни швидкості (a) та прискорення (б) узагальненої координати під час динамічного режиму гальмування

Оптимальний ривковий режим руху стрілової системи маніпулятора визначається шляхом мінімізації інтегрального функціонала 3 підінтегральною функцією у вигляді енергії ривків:

$$
I=\int_{t_{0}}^{t_{1}} E_{p}\left(t, q_{1}, \dot{q}_{1}, \ddot{q}_{1}\right) d t .
$$

Енергія ривків стрілової системи, зображеної на рис.1, буде:

$$
E_{p}=\frac{1}{2} J_{\Sigma \alpha} \dddot{\alpha}^{2} .
$$

Функції ривків стріли маніпулятора пов'язані 3 узагальнюючою координатою (підйомним гідроциліндром) наступною залежністю

$$
\dddot{\alpha}=\dddot{q}_{1} \frac{\partial \alpha}{\partial q_{1}}+3 \dot{q}_{1} \ddot{q}_{1} \frac{\partial^{2} \alpha}{\partial q_{1}^{2}}+\dot{q}_{1}^{3} \frac{\partial^{3} \alpha}{\partial q_{1}^{3}} .
$$

Після підстановки виразу (31) в залежність (30) отримаємо енергію ривків меха- нічної складової стрілової системи під час зміни вильоту вантажу, що виражається через узагальнені координати, швидкість, прискорення і ривок:

$$
E_{n}=\frac{1}{2} J_{\Sigma \alpha}\left(\dddot{q}_{1} \frac{\partial \alpha}{\partial q_{1}}+3 \dot{q}_{1} \ddot{q}_{1} \frac{\partial^{2} \alpha}{\partial q_{1}^{2}}+\dot{q}_{1}{ }^{3} \frac{\partial^{3} \alpha}{\partial q_{1}^{3}}\right)^{2}
$$

Оптимальний ривковий режим руху стрілової системи визначається рівнянням Ейлера - Пуассона

$$
\frac{\partial E_{p}}{\partial q_{1}}-\frac{d}{d t} \frac{\partial E_{p}}{\partial \dot{q}_{1}}+\frac{d^{2}}{d t^{2}} \frac{\partial E_{p}}{\partial \ddot{q}_{1}}-\frac{d^{3}}{d t^{3}} \frac{\partial E_{p}}{\partial \dddot{q}_{1}}=0 .
$$

В результаті отримуємо крайову задачу

$$
\begin{aligned}
& J_{\Sigma \alpha}\left(\stackrel{V I}{q}_{1}\left(\frac{\partial \alpha}{\partial q_{1}}\right)^{2}+\dot{q}_{1}^{4}\left(\dot{q}_{1}^{2} \frac{\partial^{6} \alpha}{\partial q_{1}^{6}} \cdot \frac{\partial \alpha}{\partial q_{1}}+15 \ddot{q}_{1} \frac{\partial^{5} \alpha}{\partial q_{1}^{5}} \cdot \frac{\partial \alpha}{\partial q_{1}}\right)+\right. \\
& +\frac{\partial^{2} \alpha}{\partial q_{1}^{2}} \cdot \frac{\partial \alpha}{\partial q_{1}} \cdot\left(6 \cdot \dot{q}_{1} \cdot{ }^{V}+15 \cdot \ddot{q}_{1} \cdot{ }^{I V}+10 \cdot \dddot{q}_{1}^{2}\right)+ \\
& +15 \cdot \frac{\partial \alpha}{\partial q_{1}} \cdot \frac{\partial^{3} \alpha}{\partial q_{1}^{3}} \cdot\left(\begin{array}{c}
{ }^{2} \\
q_{1}^{2} \cdot{ }^{I V} \\
q_{1}+4
\end{array} \dot{q}_{1} \cdot \ddot{q}_{1} \cdot \dddot{q}_{1}+\ddot{q}_{1}^{3}\right)+ \\
& \left.+5 \cdot \frac{\partial \alpha}{\partial q_{1}} \cdot \frac{\partial^{4} \alpha}{\partial q_{1}^{4}} \cdot\left(4 \ddot{q}_{1}^{3} \cdot \dddot{q}_{1}+9 \cdot \dot{q}_{1}^{2} \cdot \ddot{q}_{1}^{2}\right)\right)=0 ;
\end{aligned}
$$

3 крайовими умовами: початкові $t=t_{0}=0, q=q_{n}, \dot{q}=0, \ddot{q}=0$; кінцеві $t=t_{1}=t_{k}, q=q_{k}, \dot{q}=0, \ddot{q}=0$.

Крайову задачу розв'язуємо за методом колокацій. Розв'язок визначаємо у вигляді:

$$
\begin{aligned}
q_{1}= & q_{1 n}+\left(\frac{t}{t_{1}}\right)^{3}\left(\Delta q_{1}\left(10-15 \frac{t}{t_{1}}+6 \frac{t^{2}}{t_{1}^{2}}\right)+\right. \\
& \left.+c\left(1-3 \frac{t}{t_{1}}+3 \frac{t^{2}}{t_{1}{ }^{2}}-\frac{t^{3}}{t_{1}^{3}}\right)\right) ; \\
\dot{q}_{1}= & 3\left(10 \Delta q_{1}\left(1-2 \frac{t}{t_{1}}+\frac{t^{2}}{t_{1}^{2}}\right)+\right. \\
& \left.+c\left(1-4 \frac{t}{t_{1}}++5 \frac{t^{2}}{t_{1}{ }^{2}}-2 \frac{t^{3}}{t_{1}}\right)\right) \frac{t^{2}}{t_{1}{ }^{3}}
\end{aligned}
$$

$$
\begin{aligned}
\ddot{q}_{1}= & 6\left(10 \Delta q_{1}\left(1-3 \frac{t}{t_{1}}+2 \frac{t^{2}}{t_{1}^{2}}\right)+\right. \\
& \left.+c\left(1-6 \frac{t}{t_{1}}+10 \frac{t^{2}}{t_{1}^{2}}-5 \frac{t^{3}}{t_{1}^{3}}\right)\right) \cdot \frac{t}{t_{1}^{3}}
\end{aligned}
$$




$$
\begin{aligned}
& \dddot{q}_{1}= 6\left(10 \Delta q_{1}\left(1-6 \frac{t}{t_{1}}+6 \frac{t^{2}}{t_{1}{ }^{2}}\right)+\right. \\
&\left.+c\left(1-12 \frac{t}{t_{1}}+30 \frac{t^{2}}{t_{1}^{2}}-20 \frac{t^{3}}{t_{1}^{3}}\right)\right) \cdot \frac{1}{t_{1}^{3}} \\
& q_{1}= 72\left(5 \Delta q_{1}\left(2 \frac{t}{t_{1}}-1\right)-c\left(1-5 \frac{t}{t_{1}}+5 \frac{t^{2}}{t_{1}^{2}}\right)\right) \cdot \frac{1}{t_{1}^{4}} \\
& V \\
& q_{1}= 360\left(2 \Delta q_{1}+c\left(1-2 \frac{t}{t_{1}}\right)\right) \cdot \frac{1}{t_{1}^{5}} \\
& V I \\
& q_{1}=-720 \cdot c \cdot \frac{1}{t_{1}^{6}} .
\end{aligned}
$$

Точкою колокацій вибрано $\frac{t}{t_{1}}=0,5$ після підстановки якої в залежності (35) отримаємо неув'язку рівнянь визначивши які разом 3 виразом (34) знаходимо невідомий коефіцієнт $c \approx 0,012$.

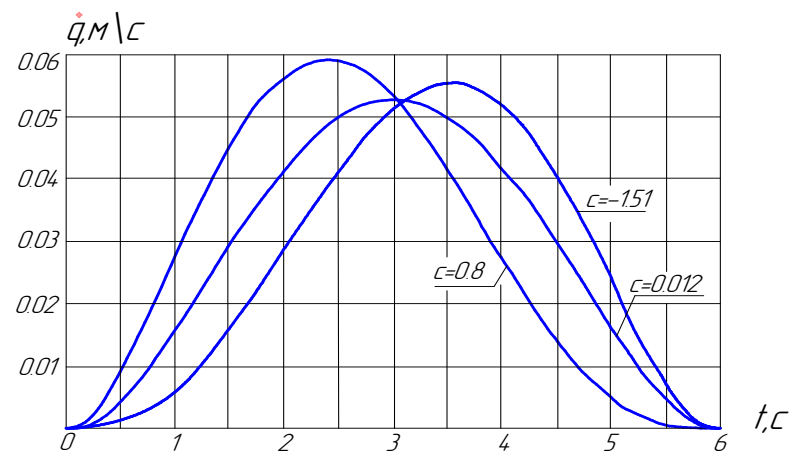

$a$.

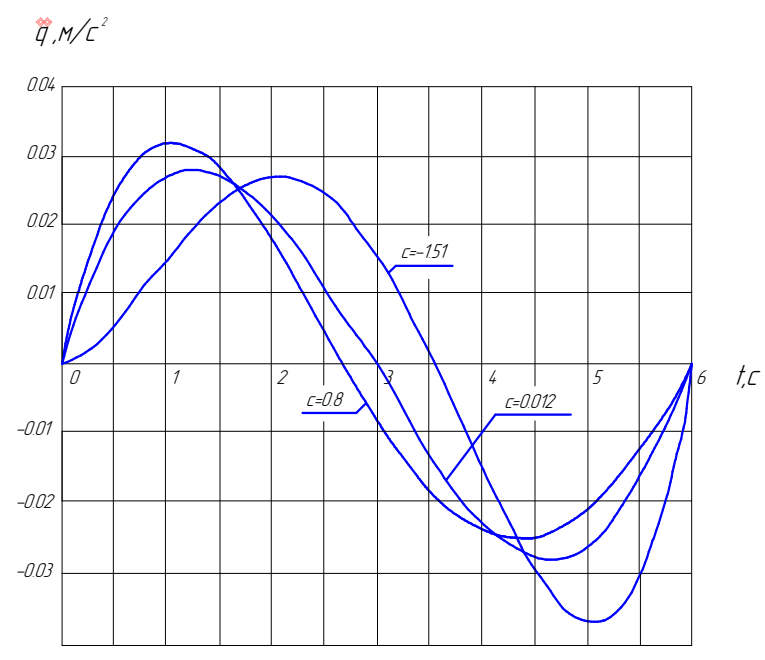

6.

Рис.5. Характер зміни швидкості (a) та прискорення (б) узагальненої координати під часривкового режиму руху за різних значень коефіцієнта $c$
Графічна інтерпретація оптимальної швидкості та прискорення під час ривкового режиму руху зображена на рис. 5 .

\section{Висновки}

Методами варіаційного числення в статті розглянуто методику розрахунку оптимальних режимів руху стріли маніпулятора під час зміни вильоту за рахунок роботи підйомного гідроциліндра.

Отримані чисельними методами із застосуванням програм математичного обрахунку (MathCAD, Mathematica) залежності швидкостей та прискорень, які дають можливість здійснити оптимальні режими руху підйомної стріли маніпулятора, створивши відповідним чином рух привідного гідроциліндра відповідно до наперед визначених залежностей.

3 розв'язків вищезазначених залежностей можемо чітко сказати, що під час руху лише підйомного гідроциліндра (рух за однією узагальненою координатою) маси ланок і вантажу не впливають на показники оптимальних режимів руху, які залежать лише від геометричних параметрів маніпулятора і показників граничних умов швидкості, переміщення та прискорення. Це дає можливість створювати більш прості системи керування маніпулятором при роздільном русі за його узагальненими координатами.

\section{Література:}

1. Л. А. Гоберман Основы теории, расчета и проектирования строительных и дорожных машин // М: Стройиздат, 1988. $-250 \mathrm{c}$.

2. В. С. Ловейкин «Расчеты оптимальных режимов движения механизмов строительных машин». Киев 1990.

3. О. В. Григоров, В. С. Ловейкін «Оптимальне керування рухом механізмів вантажопідйомних машин». Київ 1997.

4. Юрай Иринг. Проектирование гидравлических и пневматических систем Л.: Машиностроение, 1983. - 363c.

Реиензент: Назаренко І. І. д.т.н. проф. (КНУБА) 
